\title{
INNOVATION AND ENTREPRENEURSHIP IN THE COOPERATIVE ENTERPRISE: A HORNET?
}

\section{Antonio Matacena, Maria-Gabriella Baldarelli}

(1) University of Bologna, Italy

(2) University of Bologna, Italy

\author{
Antonio Matacena \\ University of Bologna, Italy \\ antonio.matacena@unibo.it \\ Article info \\ Paper category: Review paper \\ Received: 23. 6. 2015. \\ Accepted: 26. 9. 2016. \\ JEL classification: $\mathrm{M}_{41}, \mathrm{O}_{1}, \mathrm{P}_{45}, \mathrm{~N}_{5}$
}




\section{ABSTRACT HEADING}

In European economy system, one part consists of cooperatives. This paper aims to answer the following research question: "May cooperatives be considered an innovative ideal type of socially responsible enterprise?". The goal is to demonstrate that the mutual cooperative enterprises are the ideal type of innovative socially-responsible businesses and as such they have the strategic important vocation to disclose social and environmental information towards both internal and external stakeholders.

Keywords: cooperative enterprises; democracy; mutuality; accountability 


\section{INTRODUCTION}

In the period of financial crisis cooperative enterprises demonstrated to be able to face better market and financial problems using social creativity and innovation processes. The theory of cooperative enterprise needs more contributions in order to analyze the strategic and operative management features that are typically of these enterprises. Indeed, theorizing about cooperatives, especially mutualistic cooperatives, is important to underline that cooperatives are positioned in an independent kind that is separated from the not from profit enterprises and the for-profit ones.

In this paper we want to answer to the following research question: "May cooperatives be considered an innovative ideal type of socially responsible enterprise?".

Research design involves deductive and inductive approach (Franceschi, 1990).

About the deductive approach, literature is focused on mission, governance and accountability model (MGA) (Matacena, 2010) of the mutualistic cooperative enterprise in Italy, because cooperatives are strongly connected to the cultural background of the countries in which they operate.

About methodology, we use inductive approach involving one research case (Naumes and Naumes, 2006) to test our assumptions coming from deductive approach. Therefore, we will analyze the case of the Bank "Malatestiana" to implement MGA model and to answer to the research question. The tools used are the semistructured interviews, which are aimed at the entrepreneurial team and corporate management during the year 2013. About other specific areas of interviews, such as reputation analysis and governance atmosphere test we used one person that stayed there for 2 months' stage on 2012 and 2013 . A second source of data collection derives from the consultation of corporate websites and the analysis of corporate documentation: statute, ethic code, certification, internal communications pertinent to the research case, financial statements; mission and social reporting (2013; 2014).

The paper is divided in different sections. The first section contains the general definition of cooperative enterprise, in order to better understand the principles that are involved in MGA model.

The second section is involving literature review about the most important principles that are at the base of mutual cooperative enterprise, such as: mutuality and democracy.

The third section is analyzing the MGA model to combine principles in the mission, governance and accountability processes of cooperative enterprise.

The fourth section is describing the research case and then we will show some conclusions and future steps of research.

In the following paragraph we will start to describe the mutualistic cooperative. 


\section{THE COOPERATIVE ENTERPRISE: A HORNET?}

The otherness of the cooperative enterprise ${ }^{1}$ and Its diversity when compared to those profit-making ones, is to be traced back to the values and principles ${ }^{2}$. Values and principles define it and regulate it's working. Identity, values and principles have to be made evident and put into practice in a coherent way, without ever forgetting that the cooperative is an enterprise and as such has to act respecting the constraint of its business nature a constraint which weighs upon all businesses whatever their structure.

As far as the ICA is concerned, "the cooperative is an autonomous association of persons united voluntarily to satisfy their common economic, social and cultural aspirations and needs by creating an enterprise of common ownership as well as one controlled democratically". It is further established that "the cooperatives are based upon the values of self-sufficiency, self-responsibility, democracy, equality, equity and solidarity. In keeping with the tradition of their founders, the members of the cooperative believe in the ethical values of honesty, transparency, social responsibility and care towards others" ${ }^{3}$.

The above definition allows us to identify those qualifying elements of the cooperative enterprise (Matacena,1999; Negri, 2006). The first one is:" ... a production and consumption structure, which represents a protection of the workers (and over time, of consumers, savers, citizens)... and a protection of their rights of social protagonists... when faced with the degenerative processes of capitalism" (Salani, 2007:44).

The second feature of cooperative enterprise is that is acting upon the market by way of the use of a system of operative values and principles and this means that: "In cooperation ...there is a value system and a declination of it in terms of operative guidelines" (Ibidem: 45).

The third is presenting itself as market players watchful of other non-co-operator players; attention expressed by way of the teleological taking on of specific responsibilities; which evidently means a method of company management that guarantees congruence among: ends, aims, strategies and their coherence with those activities carried on in accountable management.

1 The term cooperative enterprise goes back to that experience of R. Owen in 1813 when he decided to cede his textile business, located in New Lanark, Scotland, to his employees. Remember that the cooperative movement came about, especially, where industrial capitalism was at its greatest development that is, in England, France and Germany; while in Italy, it was only in 1854, that the first cooperative was set up in Turin, this was the "Magazzino di Previdenza". See Casadio(2011) in this regard.

2 We particularly refer to the still-in-force Declaration of Cooperative Identity, a result of the congress of The International Cooperative Alliance (ICA), Manchester, 1995. This declaration contains seven principles (referred to later) that come from a precise definition of cooperative and from an explicit identification of the values that guide it.

3 Declaration of Cooperative Identity (http://ica.coop/en/whats-co-op/co-operative-identity-valuesprinciples) and Barberino, 2009: 106. 
The definition of cooperative enterprise allows us to identify the mission and the governance model present therein and to understand why the cooperative is like a hornet ${ }^{4}$, this because It takes on responsible practices in relation to the other market players who act and use the prevailing economic and profit oriented objectives and management practices.

Before to describe MGA model, in the next paragraph we will analyze same cooperatives identity principles, that are: mutuality and democracy.

\section{THE PRINCIPLE OF MUTUALITY AND COOPERATIVE MISSION: CONCEPTUAL FRAMEWORK}

Mutuality is the principle that is based on the exchange of services which comes about between members and cooperative. The exchange of services has the goal of, on the part of the cooperative, to carry out, with the contributions of the members, an economic activity directed towards supplying them goods and services at the least possible cost. Those activities are without speculative intent and more oriented to improve cooperative partners' economic, and social condition (Bonfante, 2006: 28; Bonfante, 2006b:4; Parnell, 1999).

Concretely, mutuality expresses the service that the cooperative makes to the members thanks to their contribution. Contribution whose nature normally defines the typology of cooperative, such as: workers cooperative; commercial cooperative, etc.

In other terms, it is to be considered a mutualist activity that one which is carried out, in the relationships between members and cooperative, through the elimination of capitalist intermediaries in the processes of production, exchange and labor. The activity is directed to optimize the cooperative advantage, economic or not, of the members and not to exploit a financial capital. In the cooperative enterprise capital constitutes only an instrumental factor for reaching the mutualist objective, while maintaining its function as guarantee towards third parties (Bulgarelli and Viviani, 2006:16; Holyoake, 1954: 28).

Notice, however, that what has been affirmed makes the first constraint for cooperative operations come to the surface. The second is the instrumentality of the financial capital with respect to mutualist finalization, which obviously discourage capitalist investment (Negri, 2011: 7).

The persons (as well as the needs they express) therefore represent the core of entrepreneurial attention of the cooperative as well as the entrepreneurial goal it

4. Here we refer to "the paradox of the hornet", according to which, in the case where the cooperative is interpreted with a logic of having a purely profit-making nature, it is a hornet, an insect that, on the basis of the laws of physics, should not be able to fly. The flight of the hornet is explained, notwithstanding its very small wings, by the fact that the insect manages to keep itself in the air by exploiting the turbulence created by "furious beating of its wings". The physics question is, in this case, one of "lift" which identifies the magnitude which holds an object in flight and keeps it from "stalling" and from its consequent vertical dropping. On this argument, see Barberini (2009). 
pursues (Borzaga and Tortia, 2009:24,0). Moreover, the finalization towards the goal of mutuality, pursued through the elimination of intermediary profit, facilitates the emancipation demands of the co-operator members. Then the cooperative enterprise becomes a tool for the democratization of the market as the equalization function in the processes of distribution of wealth.

In other terms, mutualist cooperative, in pursuing mutuality towards members (so-called "internal" mutuality), determines market democratization and facilitates processes of entrepreneurialization, intervening in sectors in crisis or where there absconds, precisely, an entrepreneurial answer. Finally, it makes processes of social inclusion (work opportunities, life-quality improvement ... etc.) possible.

Concretely, the cooperative - in coherence with its own finalistic intents - produces those which traditional economic theory calls "positive externalities", all this makes it acquire, since its birth, an important social function.

Mutuality therefore affirms itself as a tool to regulate relationships between members upon whom it imposes a prohibition, of a speculative use of cooperative activities for personal ends. Mutuality is useful to improve the relationship between cooperative and market requiring the cooperative to bear the burden of processes of correlation and moralization.

It is mutuality, therefore, that represents "the intangible value nucleus of cooperation" (LEGACOOP, 2006), because mutual finalization expresses itself, first and foremost, in the privilege attributed to the members to use the cooperative for the purpose of satisfying their own needs. Moreover, it allows for the presence of "speculative" aspects within cooperative management if and in that the pursuit of "profit" in such circuits is an accessory to the mutualist management and instrumental to the same and as such it cannot be distributed to members.

Essentially, the speculative intent of the member and not that of the cooperative enterprise is believed to be negative for mutuality. All this may be accepted in that the cooperative, because of finalistic assumption, has to develop the mutualist intent above and beyond the sphere of the founder members.

Within the Italian cooperative, the member neither, therefore, aims at maximizing his individual capitalist benefit, nor at maximizing the individual cooperative benefit rather he submits them to a collective utility, by putting aside returns as unavailable reserve assets and building collective wealth in order to favor, through wealth accumulation, the continuity of the enterprise and intergenerational reproduction (Costi, 2004:175; Sapelli, 2006).

In brief, ever since its origins, the cooperative generates outcomes with contents that are economic but also of a social order. It having to" scrupulously employ all revenues deriving from business with not members who use its services; if these takings are not destined to personally encourage not members to request participation. They have to be used in such a way as to let the collectivity profit and not just the members of the society. These revenues should not in any way be 
added to the management surplus to be divided among the members (Verrucoli, 1980:148).

Here we have, therefore, the "cooperative model", or rather an entrepreneurial model with the following features. The first that is internally characterized by a "sharing of returns and reinvestment of resources which is non capitalist rather mutualist, and with (...a) temporal horizon of intergenerational growth" (Mazzoli and Grazioli, 2009: 3og). This allows reducing or eliminating phenomena of the free rider and opportunism of the social basis, besides guaranteeing continuity and self-development of the cooperative and creating, within it, an amount of capital of common property. The second is that It is externally characterized by responsible and commonly agreed behavior towards third parties. This to, as was said, reach the dimensional optimum and the finalist expansion in the ultra-mutualist sense. All this permits reducing or eliminating the presence of opportunistic asymmetries which might trigger off the relationship between cooperative, external interlocutors and surrounding collectivity (Salani, 2005:172-173).

Essentially, the different nature of the mutualist cooperative enterprise when compared to those profit-making ones depends on the constitution factor: in the former, it is the community of members and the surrounding area, in the latter, it is the financial capital.

Though, to understand today, in Italy, mutuality in a "full" fashion also means, especially, tying it to the idea of solidarity and to the principle of subsidiarity ${ }^{5}$.

Indeed, solidarity, meant as common feeling of reciprocal help (self-help) which expresses itself in wishing to act together and in pursuing its own interest through the pursuit of the interests of its neighbor (Zamagni, 2002) and It is naturally connected to the mutuality found within the establishment of the cooperative.

When the influence of the cooperative grows, the mentioned solidarity "affirms itself, in respect of the principle of Commitment towards the community, is combined with the principle of subsidiarity. Surrounding community which becomes whole collectivity when the action of the cooperatives is principally directed towards the production/distribution of services of collective interest or merit/relational goods in favor of disadvantaged players.

In short, we introduce the concept of "extended mutuality" and give life to cooperative enterprises, the so-called "multifunction or multi-stakeholder cooperatives" (Barberini, 2009:121), where the pursuit of meta-economic objectives is considered teleological assumption, that is, an element that qualifies the mission.

In this case, cooperatives are directed towards the production/distribution of wealth, both economic and social, activities that favor the collective welfare and that also permit the improvement of the overall efficiency of the market.

In other words, especially in Italian practice, a close connection between mutuality and solidarity has been proposing itself together with an evolution of internal

5 As regards the topic of the benefits directly and indirectly induced on the collectivity by the entrepreneurial cooperative forms, see Borzaga, Tortia (2004). 
mutuality towards an external one, which reveals itself more and more as a solidarity behavior of subsidiary nature. Behavior to consider as a corrective of an "unbridled" economic liberalism. This has come about by way of the emerging of social cooperatives.

With the social cooperatives does internal mutuality abate, whilst their specific finalization emerges and which is that of creating collective utilities of an economic and social nature (the so-called collective benefit) linking the activity of the social cooperative to that of the welfare state. With social cooperatives emerges a special category of business: that directed to pursuing specific interests of a collective nature so as to promote the integration of citizens. This category of cooperative also characterized by a further element, such as: the possible presence within it of players different from internal members (such as: volunteer members, investors, etc.) with clear outcomes of widening the problematic issues relating to internal governance.

All this comes about, however, only if the cooperatives widen their dimensional impact, come onto the social market and go so far as to directly involve a greater number of players to whom they are accountable for their being both economic and social players (Bulgarelli and Viviani, 2006: 19).

All this may be done, however, only if there is a mechanism of the exercise of property rights, which traces back its founding lemmas in equality and in the equal dignity of players. A governance therefore where cooperative management performs management behavior of a commonly agreed nature aimed at favoring the internal balancing of interests (Salani, 2005:170). Moreover, governance pursue the interests of co-operator members (in terms of not discrimination of one member in relation to another) and in which interests of the cooperative movement he belongs to, of not members, and of specific single and collective stakeholders (in terms of respect for social finalization pursued).

That which has been said leads us to examine the principles regulating governance within the cooperatives (Marcon, 2008: 26). About corporate governance we mean the modalities by which the structure of the enterprise is determined and the relations between players who operate therein are regulated. Essentially, speaking of the corporate governance of a cooperative means examining: the relationships between property and administrators and administration and control models adopted therein. This is the subject of the following section.

\section{THE PRINCIPLE OF DEMOCRACY AND COOPERATIVE GOVERNANCE: CONCEPTUAL FRAMEWORK}

If in external relations the cooperative may appear a socially responsible economic player, internally it is characterized to accept the principle of the democratic nature. A principle that is made clear, through the known postulates of the "open door" and of "one member, one vote" (Jossa, 2010:4,8). 
With the first postulate mentioned - made plain by the Principle of free and voluntary participation according to which: "Cooperatives are voluntary organizations open to all people able to use their services and who wish to accept the responsibilities connected with becoming a member, without any kind of: gender, social, racial, political or religious discrimination" (Bonfante, 2011:2-3).

By the cooperative itself, becomes clear interests which are homologous and locally contiguous, owing to the obligatory existence of mutualist exchange and the already known principle of commitment towards the community, to those of already active members; a right which is not subject to any constraint of a discriminatory nature (Reali, 2011:71).

This right of participation is essential for the cooperative enterprise given that its mutualist finalism imposes the involvement of growing quantities of members upon it and determines the open nature of the cooperative organization. Even more, it indirectly reaffirms the prevalence of the mutualist relationship as regards capitalist contribution.

Moreover, we have to clearly understand, however, that in the case where the cooperative does not permit the exercise of this right the broadening of the social base however, must be made possible by it through an action of "cooperative promotion" facilitating the creation of a new cooperative competitor, carrying on, therefore, an obligatory activity of business incubator.

The "open door" and cooperative promotion identify elements of the cooperatives, such as: mechanisms of social inclusion; mechanisms of economic development of the area where the cooperatives operate; growth factors of the "human and professional subjective qualities of those belonging to the community" (Salani, 2005: 179; Borzaga, Depedri and Galera (2010: 125-146).

All this permits the cooperative to origin itself in the area it operates in (Matacena (2009:57-58) and to become, for the same, a fundamental generator of relational capital and of community identity (Salani, 2005; Vella, 2010:154; Putman, Leonardi \& Nanetti, 1994).

It should not escape anybody, however, that territorial taking root, essentially a condition of not being able to decentralize matters, highlights the second constraint for cooperative activity: that one connected to possible development of the productive dimension.

The men and the women elected as representatives are accountable to the social base. In first-degree cooperatives, the members have the same rights to the vote (one member, one vote); also the cooperatives of other degrees are equally organized in such a democratic way (Bonfante, 2011:29; Tessitore, 1973 and 1990). We point out that, since the beginning, in the same cooperatives there are conditions of: "selfmanagement" (in those that use remunerated, non-remunerated and/or charity social work); "direct participation" (in those where members bring goods or services different from their own type of labor and/or acquire goods and services produced by the cooperative) (Matacena, 1999). 
It is clear, however, that the self-management or participation substantially exclude both the mutualist contribution, and the capitalist one but they are connected to the being a member (remember - "one member, one vote"). Essentially, the "percapita vote", however, does not allow fully valuating the intensity of mutualist contribution and the quality of participation to cooperative life of every single member; all this highlights the third constraint for cooperative action. This that connected with administrative difficulties resulting from eventual disparities in the treatment of members and from social absenteeism which might derive from them.

Moreover, this latter postulate determines basic institutional layouts and specific running rules of mutualist cooperatives, different from the homologous ones in profit-making businesses.

To conclude, democratic governance, linked with the finalism pursued, should allow the cooperative enterprise to place within itself stable relationships of coordination among members, workers, manager and other third parties. Especially if it is a matter of social cooperatives, where the mission pursued is a prevalently social one, being called upon to generate utility of a principally collective nature.

In the following Table 1 . we can see in synthesis mission and governance of cooperative enterprise.

Table 1.: MG (Mission and Governance) in the mutualist cooperative enterprise

\begin{tabular}{|c|c|}
\hline MISSION & CORPORATE GOVERNANCE \\
\hline PLAYERS: CO-OPERATOR MEMBERS & PLAYERS: COOPERATIVE ENTREPRENEUR \\
\hline $\begin{array}{l}\text { Mutualist benefit, that is, optimization of returns } \\
\text { of social contributions, in whatever form they } \\
\text { are carried out. This optimization of returns is } \\
\text { in compliance with the constraint of corporate } \\
\text { nature and in the necessary pursuit of cooperative } \\
\text { objectives and collective solidarity. Moreover, it is } \\
\text { in accordance with the specific social aspirations } \\
\text { that are internally matured, and in agreement } \\
\text { with the indications of the cooperative movement. } \\
\text { Mutualist benefit which is accomplished by: } \\
\text { 1. making the widening of the rights of } \\
\text { members possible; } \\
\text { 2. generating positive externalities; } \\
\text { welcoming specific types of mission of an } \\
\text { Multidime-economic nature. }\end{array}$ & $\begin{array}{l}\text { Corporate governance is implemented in } \\
\text { respect of the principle of the "open door" and } \\
\text { of its democratic nature. It is achieved through } \\
\text { management behavior, that is aimed at favoring } \\
\text { the balancing of the interests of the co-operator } \\
\text { members, and those of the cooperative movement } \\
\text { and of individual and collective stakeholders. } \\
\text { Corporate governance is characterized: } \\
\text { 1. by running rules, that are centered on } \\
\quad \text { the equal dignity of members and on the } \\
\text { authoritativeness of manager members; } \\
\text { by relations, between members and } \\
\text { cooperative, which find the elements that } \\
\text { determine loyal and faithful behavior of } \\
\text { members as regards their cooperation in } \\
\text { equality and reciprocity. } \\
\text { Governance is characterized by the principle of } \\
\text { solidarity } \\
\text { Potentially Multi-stakeholder Governance. }\end{array}$ \\
\hline
\end{tabular}

Source: Autors' elaborations

After the analysis of mission and governance, in the next paragraph we will develop the content of mission, governance and accountability model. 


\section{THE ACCOUNTABILITY OF COOPERATIVE ENTERPRISE AND MISSION AND GOVERNANCE RELATIONSHIPS: MGA MODEL}

We accept the hypothesis that company communication is a necessary tool for guaranteeing appropriate and loyal company-environment interaction processes. To analyze the cooperative information system, from where communication flows, we would need to verify that the company information systems were structured in such a way as to offer data useful for the decision and for the control of the results (data, that is, both for internal and external use). Moreover, the company information systems were the result of an explicit correlation between: objectives pursued by the individual company; organizational structure, which, having acquired the objectives to pursue, defines and implements strategies and policies necessary to their attainment and the whole of accounting, and not accounting procedures aimed at producing the information needed to decide and to control.

This all adds up to affirm that in all enterprises, explicit and coherent coordination between mission and governance should exist, and both the typology and level of accountability, there, should derive from the coherence of this coordination. Moreover, modifications to the mission, where they come about in an enterprise, should reflect onto the governance therein (and vice versa), with the obvious result that these modifications should have an effect upon the typology and the level of accountability (Matacena, 1999, 2010).

If this is valid, assuming full coordination between objectives of the cooperative and its information system. Broadly, assuming that the mutualist, solidarity and social mission pursued by way of a democratic type of governance, produces results made evident in terms of effectiveness, efficiency and productivity. There is the need therein of an information system able to coordinate, during the phase of strategic implementation, the mutualist, solidarity and social ends with the economic and financial constraint. Moreover, the information system will define the qualify / quantify the degree of mutualist, solidarity and social ends achieved, defining its incidence also in terms of economic-ness, solvency and capitalization. Finally, it must allow third parties, both internal and external ones, on the basis of specific options, to valuate such performances or constraints, in order to validate them or not.

Summing up, the accountability of a mutualist cooperative, developed towards social aspects, should be characterized by the co-presence of accounting information tools, and others. These tools should firstly guarantee the forms of management control aimed at verifying the subsistence of the condition of corporate nature, continuity and level of mutualist benefit in an economic sense, generated by cooperative activity. Secondly it will provide forms of institutional control aimed at verifying extra-mutualist impact, that is, solidarity and social impact, of the cooperative.

With regard to the first point, analysis of the level of mutuality may be dealt with informing on how the wealth structure, the financial situation and the economic re- 
sult of the period of the individual cooperative, depend on and / or derive from flows of interexchange between member and cooperative.

Said information can be obtained through an analysis of the mandatory report of the financial year, an analysis that highlights accounting entries that explain said interconnections and weighs up their incidence in terms of being and becoming of the cooperative enterprise.

It will be a matter of, essentially, verifying the level of funding deriving from mutualist exchange and of the incidence of said funding in comparison with that resulting from the same mutualist exchange. Moreover, it will record and inform about the level of return of these contributions in the hypothesis that the pursued mutualist benefit is that deriving from management behavior aimed at optimizing all remunerations that may be attributed to the member. Optimization of remunerations, that presupposes management policies that privilege social returns but never to the detriment of the capacity for self-development of the cooperative.

Informing on internal mutuality pursued and reached essentially means accounting for the degree of financial dependence of the cooperative on contributor members, leaving, to the mandatory accounting documents.

These documents must give information about capitalization, which may be obtained by way of a vertical analysis of the active and passive entries of the statement of assets and liabilities. Information about finance and solvency situation, information which may be obtained by way of a horizontal analysis of the active and passive entries concerning the statement of assets and liabilities and by way of an analysis of the liquidity report. Moreover, it is need to know economic situation - information which may be obtained via close examination, in terms of efficiency and productivity, of the area of balance sheet. It is required to begin a process of successive separation of characteristic mutualist management from the characteristic profit-making management (that is, carried out with not members). That is in order to measure the result of the latter and its incidence on the overall characteristic management and to analyze modalities of use of the result if positive (Venditti, 1996:78).

With regard to institutional-type communication it must be, first of all, clarified that the said communication represents an identity obligation and not just a mere voluntary taking on of an obligation (or a law obligation) for the cooperative. Especially if we remember the Fifth Principle of the Declaration of cooperative identity (Education, Training and Information) which in the final paragraph establishes: "Cooperatives start information campaigns for the purpose of raising public opinion, particularly the youth and the well-known opinionates to the nature and benefits of cooperation". It is well knowing that the nature of said benefits (as above seen: positive externalities, increase in relational capital, protection of surrounding areas) are not easily quantifiable in monetary terms or using indicators of an economic nature (Vannini, 2005:139-155).

All this may be summarized in the following Table 2., which coordinates cooperative mission and governance at the level and typology of accountability therein. 
Table 2.: MGA (Mission Governance and Accountability) in mutualist cooperatives

\begin{tabular}{|c|c|c|}
\hline MISSION & $\begin{array}{l}\text { CORPORATE } \\
\text { GOVERNANCE }\end{array}$ & ACCOUNTABILITY \\
\hline $\begin{array}{l}\text { PLAYERS: CO-OPERATOR } \\
\text { MEMBERS }\end{array}$ & $\begin{array}{l}\text { PLAYERS: COOPERATIVE } \\
\text { ENTREPRENEUR }\end{array}$ & PLAYERS: CONTROLLERS \\
\hline $\begin{array}{l}\text { Mutualist benefit, that is, } \\
\text { optimization of returns of social } \\
\text { contributions, in whatever } \\
\text { form they are carried out. } \\
\text { This optimization of returns } \\
\text { is in compliance with the } \\
\text { constraint of corporate nature } \\
\text { and in the necessary pursuit } \\
\text { of cooperative objectives and } \\
\text { collective solidarity. Moreover, } \\
\text { it is in accordance with the } \\
\text { specific social aspirations that } \\
\text { are internally matured, and in } \\
\text { agreement with the indications } \\
\text { of the cooperative movement. } \\
\text { Mutualist benefit is also realized } \\
\text { with: } \\
\text { 1. making possible the } \\
\quad \text { widening of the rights of } \\
\quad \text { members; } \\
\text { generating positive } \\
\quad \text { externalities; } \\
\text { 3. welcoming specific } \\
\quad \text { missions of an ultra- } \\
\text { economic nature. } \\
\text { Mission is therefore founded } \\
\text { upon: self-help, "proselytism", } \\
\text { territorial and intergenerational } \\
\text { impact. } \\
\text { Multi-dimensional mission }\end{array}$ & $\begin{array}{l}\text { Corporate governance is } \\
\text { implemented in respect of } \\
\text { the principle of the "open } \\
\text { door" and of its democratic } \\
\text { nature. It is achieved through } \\
\text { management behavior, that is } \\
\text { aimed at favoring the balancing } \\
\text { of the interests of the co- } \\
\text { operator members, and those } \\
\text { of the cooperative movement } \\
\text { and of individual and collective } \\
\text { stakeholders. } \\
\text { Governance is characterized } \\
\text { by the principle of solidarity, } \\
\text { which, at the same time, } \\
\text { represents an "organizational } \\
\text { factor". Moreover, it is an } \\
\text { element of interconnection } \\
\text { among: cooperative enterprises, } \\
\text { enterprise system and system } \\
\text { of representation (as identity } \\
\text { element which binds the } \\
\text { cooperative to the movement } \\
\text { that contains it). Cooperation } \\
\text { governance is an organizational } \\
\text { mechanism, that is based on } \\
\text { solidarity thanks to which the } \\
\text { acquisition of certain goods } \\
\text { on the market is easier in the } \\
\text { collective, rather than in the } \\
\text { individual form". } \\
\text { Potentially multi-stakeholder } \\
\text { governance }\end{array}$ & $\begin{array}{l}\text { Potentially information } \\
\text { system from, which is } \\
\text { aimed at bringing forward } \\
\text { communication to pursue the } \\
\text { controlling of the mission } \\
\text { by way of the checking of the } \\
\text { results. The main results are: } \\
\text { 1. } \quad \text { management results, } \\
\text { useful for verifying the } \\
\text { condition of the corporate } \\
\text { nature and of the level } \\
\text { of internal mutualist } \\
\text { finalism achieved; } \\
\text { Institutional results, } \\
\text { useful for verifying } \\
\text { the level of external } \\
\text { mutualist, that is finalism } \\
\text { achieved and of the } \\
\text { specifically undertaken } \\
\text { social responsibilities. } \\
\text { Overall control for all } \\
\text { stakeholders. Control that } \\
\text { may be: before, during } \\
\text { and after the cooperative } \\
\text { activity. This control is } \\
\text { actuated for the purpose } \\
\text { of guaranteeing intra- } \\
\text { cooperative dialogue. }\end{array}$ \\
\hline
\end{tabular}

Source: Authors' elaborations

All this prompts us to deduce the content of the institutional communication of the mutualist cooperatives, at least the minimum content, from the interpretative paradigm $\mathrm{M}<->\mathrm{G}<->$ A presented above.

With regard to the mission, the mutualist cooperatives are qualified as systems with the aim of producing economic benefits for, first of all, members and, eventually over time, economic and social benefits for a more or less broad collectivity and surrounding area. The solidarity-social aims can finalize mutualist management of cooperatives, while respect for economic and financial balance constitute, for them, a necessary condition for guaranteeing their survival, continuity and development. 


\section{THE IMPLEMENTATION OF MGA MODEL IN THE COOPERA- TIVE BANK "MALATESTIANA"}

We decided to focus our attention on the case of Malatestiana Bank, because on 2014 It celebrated 100 years of activities, as you can see from the picture that is representing the first record of S. Vito Bank on 1914, that in 2002 became part of the present bank.

Figure 1.: The first record of S. Vito Bank on 1914

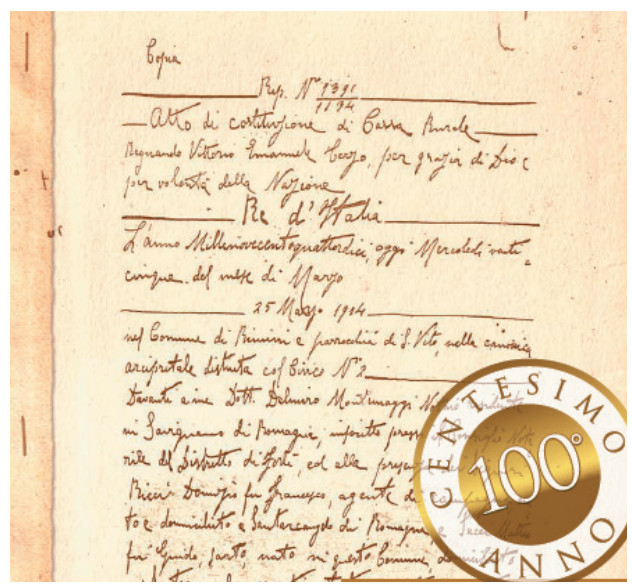

Source: S. Vito Bank

Indeed, Malatestiana Bank had been the result, in 2002, from the fusion of two Cooperative Credit banks (BCC) almost centenarian: BCC of San Vito and Santa Giustina, and BCC of Ospedaletto. Both of them had been founded in the years before the First World War (1914) as a result of the social action promoted by the Church. This strain was expressed in the encyclical of Pope Leo XIII: "Rerum Novarum", which promoted the cooperation as a necessity to deal with conflicts and abuses that were in the society of that time.

A present the total amount of patrimony of the Bank at the end of 2014 is: 9.101.423,00 and It is the first BCC in the territory of Rimini with 4.885 members and an increase of them 22.7\% from 2010 to 2014. The Bank is operating in Rimini Province- Italy with 28 agencies.

The mission of the cooperative is oriented to support the responsible and sustainable development of the territory as local bank serving the local area. Territoriality allows the bank to operate there through the collection of savings and then to mainly finance the enterprise members and the others of Rimini territory.

From the Statute on the bank, we can read, in the Art. 2, that mutuality is the main objective of the bank. They consider the different typologies of mutuality that 
we analyzed before, such as: internal and external mutuality to the benefit of members and without speculative objectives.

About mutuality, we can underline the attention to the cooperative networks and territory social community.

Finally, the mission is based on cooperation and cohesion along with: respect, honesty and prudence. The Ethics Chart of BCG contains the guidelines to consider in the mission of the bank.

Especially, the principal objective is to "create trust" (Ethics Chart -Art.2). Another important principle (ART. 6) is that the income resulting from enterprise management is a measure of the cooperative managerial skills and organizational efficiency. It represents, at the same time, the wealth to share, to promote the welfare of cooperative members and the local area.

For the purpose of orientation to corporate social responsibility (CSR), On December 2009, the Board of Directors decided to meet all cooperative personnel organizing a convention during which the mission of the Bank had been analyzed from the point of view of "cultural and emotional features". These activities had the aim to make all employees more aware of sharing values.

The governance of Malatestiana Bank is involving democracy and the "door open „trying to satisfy members at first and all stakeholders too.

The most important governance organ is the Board of Directors, that is composed by 9 members. Among its members, the president is a woman and another member is a woman too.

The commitment of Bank Malatesta is not only aimed at improving the economic conditions of its members, but also the realization of initiatives and non-banking benefits to the members in relation to the principles and values, such as: solidarity and cohesion. Moreover, there are initiatives, including social appointments, social visits and scholarships. Relations with investors are focused on the transparency of financial, economic and social information.

The regulatory structure constitutes a system of governance aimed at prudent governance and internalization of the values, which the BCC are carriers. These values have led to a shift from the formal respect to innovation in social responsible governance. The accountability of the bank is based on different documents, but we will analyze some of them, such as: financial statement, mission and social report and other indicators about mutuality principle implementation.

About financial results, despite the financial crisis in 2011, which reduced the credit to the whole economy system, the network of Cooperative Banks was able to reaffirm its vocation claiming the territory, its customers and its members, by providing them the credit. The Bank, despite a reduction of net income in December 2011, maintained the equal amount of total deposits and lending to customers with a small increase of its members. 
The Margin of Intermediation of 2014 had been 60,4 with an increase of $10 \%$ compared to that of 2013 .

Regarding the economic situation, the indexes that were found to be most relevant are the following Table 3.

Table 3.: Economic Performance Indicators 2014

\begin{tabular}{|l|r|r|}
\hline \multirow{3}{*}{ Profitability } & Intermediation Margin & $60,4(+10 \%)$ \\
& R.O.E.(Net Income/ Total Assets) & $1 \%$ \\
& Gross Operational Margin/Total Assets & $16.6 \%$ \\
\cline { 2 - 3 } & Interest Margin/Intermediation Margin & $4,3,6 \%$ \\
\hline
\end{tabular}

Source: Financial statement 2014

About social and environmental accounting and accountability, the bank obtained some certifications, such as: ISO 9001; ISO 14,001 / EMAS; SA8000; OHSAS 18001. The Bank decided to publish mission and social report starting from 2002, with the aim to "communicate in a clear and honest activities carried out", trying to verify "together with its partners" its mission based on the principles of mutuality and democracy. So the bank tried to demonstrate how Its governance can be defined as "different", especially if has satisfied the condition of reciprocity translated into benefit for the members.

The Bank uses the mission and social report for a better definition of its corporate identity, and aims to improve dialogue and commitment with all stakeholders. So, it is able to ensure a fair exchange of information and to provide, in a transparent way, a guide to all the activities. This work turns into the increase of internal and external "reciprocal trust".

In the following table we are going to see the Distribution of Value Added 2014.

Table 4.: Distribution of value Added- 2014

\begin{tabular}{|l|r|}
\hline Members & 317.396 \\
Personnel & 15.842 .929 \\
Suppliers & 8.686 .134 \\
Territory community & 499.944 \\
Cooperative movement & 82.459 \\
Public Administration & 8.023 .937 \\
Value added distributed & $33.317 .5^{31}$ \\
Malatestiana Bank & 2.038 .617 \\
\hline
\end{tabular}

Source: Mission and social reporting 2014 (millions of Euros)

The evaluation of the performance of the cooperative mutual is important to verify compliance with the principles of cooperation.

For BCC are stated some "Social Performance Indicators", that are developed by the Federation of Italian BCG (Federcasse 2011) and in the absence of 
adequate compulsory disclosure. We can see some examples of these indicators: social performance indicators; presence of women in the corporate organs; discrimination; presence and participation of women in the social; number of members that take part in the assembly the attention to araining; training hours per capita; mutuality and attention distribution to members; donations; value added distributed to members; solidarity and attention to community; donations to community; donations / net Interest. In the Bank these indicators turn out to be quite positive.

After the description of the case, in the next paragraph we are going to show discussion and conclusion.

\section{DISCUSSION AND CONCLUSION}

In this paper we analyzed MGA model theory about mutualistic cooperatives and we described the implementation the model to the Bank "Malatestiana".

We verified that the principles of cooperative enterprises, such as mutuality and democracy, are implemented in the case and are represented in accountability. Especially mission and social report is essential to check and to report the activities performed by the cooperative. It is involving the values constituting its identity and with the commitments made with the various stakeholders, that are declared in the mission. In fact, the concept of social responsibility in mutual cooperatives already implies, finding its legitimacy in the statute of the enterprise. Mutuality in all its forms (internal, external, network) and democracy that characterize the mission and governance of mutual cooperatives represent the otherness that should be considered in such enterprise, namely their "diversity". Such "diversity" should be expressed through innovation in governance behavior but also through a responsible use of the information system and accountability.

As for the needs of accountability, the administrative control of the results should be used to verify that they meet the legal rules. Management control should, however, be useful to define the internal objectives, that the cooperative achieved in terms of mutuality. The institutional aims are measured by the efficiency and social solidarity. Both dimensions: administrative and management are closely linked with the so-called legal accountability and therefore considered to be essential, as the financial statements derived from statutory provisions. The institutional dimension, most linked to the external reporting of the effects of the business, is voluntary accountability, that is not prescribed by law, but to which each company is free to decide whether to adhere or not, without incurring any sanctions.

Finally, we can answer to the research question: "May cooperatives be considered an innovative ideal type of socially responsible enterprise?". We showed about mission, governance and accountability model that cooperatives may be an innovative ideal type of socially responsible enterprise. 
This because the importance attributed to certain values in the adoption of the social reporting process, have shown particular attention to the innovation in strategic value. In fact, in terms of governance, social accountability is important in terms of relationships with the Authorities. Authorities, that in the case of BCC have fundamental models proposed by ABI (Italian Banking Association) and the Italian Banking Association for Federcasse for the preparation of Social Report in the specific case of the BCG. The legitimacy is essential in the BCG to meet the characteristics required from them, because they belong to a system ("network system") that determines the political-strategic addresses credit unions.

The sense of belonging to a collaborative system is very strong and the regulatory pressures derive precisely from this status that result for the BCG, through the publication of mission and social report as an important tool in terms of values within the enterprise.

Moreover, it is thus able to increase the value of the organization and human resources, in terms of increased communication and dialogue and a continuous quality improvement and collaboration with other BCC associated with the system, trying to convey and reinforce identity values.

The awareness of belonging to a particular system that is named: "cooperative network", and want to share values such as: participation, cooperation and reciprocity, means that, even with regard to the hiring of conduct designed to CSR, it has an even take all internal of the system itself. Clearly also, the implementation of social responsibility policies has costs, but the convenience is the entrepreneurship innovative competitive advantage, that can be achieved only through a sincere adherence in terms of process to internalize values and principles, that underpin CSR.

In conclusion the cooperative is able to challenge the traditional economic and enterprise rules like a "hornet" that didn't fly using traditional physical rules. On the contrary, the "hornet" is able to fly as if the cooperative is able to easily survive especially in periods of crisis.

The limit of the paper is that we considered only one case about inductive approach. In the future steps of research, we will consider some others empirical cases to implement the theory. 


\section{REFERENCES}

ALLEANZA COOPERATIVA INTERNAZIONALE, Dichiarazione di identità cooperativa approvata al Congresso di Manchester, 1995

Baldarelli, M. G. "Le dimensioni della responsabilità sociale: riflessioni su miti e paradossi in una prospettiva economico-aziendale." Rivista Italiana di ragioneria e di economia aziendale 1, no. 2 (2009): $59^{-69}$

Barberini, Ivano, and Miriam Accardo. Come vola il calabrone: cooperazione, etica e sviluppo. Vol. 388. Dalai editore, 2009

Bonfante, Guido. La legislazione cooperativa: evoluzione e problemi. Giuffrè, 1984

Bonfante G. I principi della cooperazione e le grandi imprese cooperative, in AA.VV., Studi in onore di Gastone Cottino, Cedam, Padova, 1998

Bonfante G., Attività mutualistica e ristorni: aspetti sostanziali e clausole statutarie, in Borzaga G., Fici A., La riforma delle imprese cooperative, Edizioni31, Trento, 2004

Bonfante G., Legislazione e promozione cooperativa, in Bulgarelli M., Viviani M. (a cura di), La promozione cooperativa, Il Mulino, Bologna, 2006a

Bonfante G., La società cooperativa europea, in Fici A., Galletti D. (a cura di), La società cooperativa europea. Quali prospettive per la cooperazione italiana?, Quaderni del Dipartimento di Scienze Giuridiche n. 61, Università di Trento, Trento, 2006b

Bonfante G., Manuale di diritto cooperativo, Zanichelli, Bologna, 2011

Borzaga C., et al., L'interesse delle cooperative per la comunità, in Borzaga C., Ianes A., L'economia della solidarietà. Storia e prospettive della cooperazione sociale, Donzelli Editori, Roma, 2006

Borzaga C., Tortia E., Dalla cooperazione mutualistica alla cooperazione sociale, CLEONP, Facoltà di Economia di Forlì, Working Paper n. 6, Forlì, 2004

Borzaga C., Tortia E., Cooperativa (impresa), in Bruni L., Zamagni S. (a cura di), Dizionario di economia civile, Città Nuova, Roma, 2009

Buonocore V., Diritto della cooperazione, il Mulino, Bologna, 1997

Bulgarelli M., Viviani M., Introduzione. La promozione, la mutualità e i "diritti dell'impresa", in Bulgarelli M., Viviani M. (a cura di), La promozione cooperativa, Il Mulino, Bologna, 2006

Capaldo G., Presentazione del progetto di ricerca "Gli strumenti di finanziamento dell'impresa cooperativa", in Caleo O., Il finanziamento dell'impresa cooperativa, ISICCOP, Roma, 2008

Costi R., Relazione di sintesi, in Borzaga C., Fici A. (a cura di), La riforma delle imprese cooperative, Edizioni31, Trento, 2004

Depedri S., Tra motivazione intrinseca ed economica. Un nuovo modello di relazioni industriali nelle cooperative sociali, Dipartimento di Economia, Università degli Studi di Trento, 2010

DIREZIONE GENERALE DELLA COOPERAZIONE (a cura di), I principi della cooperazione nella dichiarazione dell'Alleanza Cooperativa Internazionale, Roma, 1969

Freeman E., Strategic planning. Astakeholder approach, Pitman, Boston, II Edt, 1984

GUI B., Bene relazionale, in BRUNI L., ZAMAGNI S. (a cura di), Dizionario di economia civile, Città Nuova, Roma, 2009 
Hansmann H., La proprietà dell'impresa, il Mulino, Bologna, 2005

Hansmann H., Intervento, al Seminario: La proprietà dell'impresa cooperativa, Centro Studi Legacoop, Roma, 2006

Holyoake G. J., La storia dei probi pionieri di Rochdale, in Rivista della Cooperazione, 1954

INTERNATIONAL COOPERATIVE ALLIANCE [I.G.A.], Declaration of cooperative Identity approved at the Manchester Congress, 1995

Jossa B., Le cooperative di produzione e la teoria economica, in Cuomo G., Jossa B. (a cura di), Le imprese cooperative, Carocci, Roma, 2010

LEGACOOP (2006), I cooperatori protagonisti del futuro italiano, Documento Congressuale approvato il $22 / 11 / 2006$.

Marcon G., Una nuova visione per l'impresa cooperativa nel solco consolidato dell'economia sociale, in Salani M. P. (a cura di), Nuove lezioni cooperative, il Mulino, Bologna, 2008

Matacena A., Impresa e ambiente: il bilancio sociale, CLUEB, Bologna, 1984

Matacena A., Impresa cooperativa. Obiettivi finalizzanti. Risultati gestionali e bilancio d'esercizio, CLUEB, Bologna, 1990

Matacena A. (a cura di), Azienda non profit. Scenari e strumenti per il terzo settore, EGEA, Milano, 1999

Matacena A., La responsabilità sociale dell'impresa: dal "capitalismo dell'età dell'oro" al "turbo capitalismo", in Matacena A., Del Baldo M. (a cura di), Responsabilità sociale d’impresa e territorio, Angeli, Milano, 2009

Matacena, A. "Corporate social responsibility and accountability: Some glosses." Civil economy, democracy, transparency and social and environmental accounting research role, 2010: 7-59

Mazzoli M., Grazioli R., La governance partecipata, in Mazzoli M., Benati B. (a cura di), Partecipazione ricerca innovazione, Editrice La Mandragora, Imola, 2009

NegriZ. V., L'impresa cooperativa italiana: dalla marginalità alla fioritura, Relazione al XIV ${ }^{\circ}$ Congresso Internazionale di Storia Economica, Helsinki, 2006

Negri Z. V., L'impresa cooperativa: residuo del passato o proposta per una società più equilibrata? in, Lezioni Rossi-Doria, 2010

Parnell E., R/einventare la cooperativa, Liocorno, Roma, 1999

Reale M. P., Le cooperative tra diritto ed economia, in Cuomo G., Jossa B. (a cura di), Le imprese cooperative, Carocci, Roma, 2011

Salani M. P. (2005), Le basi istituzionali della forma cooperativa, in Zamagni S., Salani M. P., La cooperazione come best practice di RSI, in AA.VV., L'orientamento responsabile, Camera di Commercio di Pescara, Pescara, 2007

Sapelli G., Coop. Il futuro dell'impresa cooperativa, Einaudi, Milano, 2006

Travaglini C., Cooperativa sociale, in Bruni L., Zamagni S. (a cura di), Dizionario di economia civile, Città Nuova, Roma, 2009

UNIONCAMERE, Secondo rapporto sulle imprese cooperative, Quaderno Unioncamere, Roma, 2005

Vnditti M., Caratteri economici delle imprese cooperative, Giappichelli Editore, Torino, 1995

Verrucoli P., I principi della Alleanza Cooperativa Internazionale e la loro applicazione nella legislazione 
italiana, Rivista della Cooperazione, 1980

Zamagni S., L'economia delle relazioni umane, in Sacco P., Zamagni S. (a cura di), Complessità relazionale e comportamento economico, il Mulino, Bologna, 2002

Zamagni S., Responsabilità Sociale delle Imprese e "Democratic Stakeholding", Working Paper n. 28, AICCON, Forlì, 2006

Zamagni S., Cooperazione, AICCON Ricerche, Forlì, 2012 
